\title{
Seawater Icicles of the Adriatic Sea
}

\author{
Vlado Malačıč and Nedjeljka Žagar
}

BACKGROUND: SEAWATER ICE AND ICICLES. The major characteristic of ice formed of seawater is that it contains salts, and its salinity is measurable (Cox and Weeks 1974). The U.S. National Snow and Ice Data Center (http://nsidc.org/cryosphere /seaice/index.html) offers the most comprehensive approach to this question. Sea ice (and sea icicles) is common in polar and subpolar regions (Ehn et al. 2007).

Freshwater icicles are also frequent in continental midlatitude areas, including inland regions around the Mediterranean Sea. In contrast, marine icicles that form on coastal constructions (e.g., on piers and railings) are relatively rare events in the Mediterranean. The freezing point of seawater depends on salinity. For salinities around 37 practical salinity units (PSU; UNESCO 1978), which is typical for the Mediterranean, the freezing point is around $-2 \cdot 1^{\circ} \mathrm{C}$. The freezing point decreases as salinity increases so that for every 5 -PSU increase, the freezing point decreases by $0.28^{\circ} \mathrm{C}$ (https://nsidc.org/cryosphere/seaice/characteristics /brine_salinity.html).

The northern Adriatic Sea, the subject of the present study, is characterized by winter temperatures of around $10.5^{\circ} \mathrm{C}$, and salinity of around $37.3 \mathrm{PSU}$ (Artegiani et al. 1997a). During the winter months, the salinity varies from zero at the mouth of rivers to a maximum of about 38.4 PSU (Artegiani et al. 1997a). The minimum recorded sea surface temperature (SST) of the northern Adriatic Sea is about

\footnotetext{
AFFILIATIONS: MALAČIČ-National Institute of Biology, Marine Biology Station, Piran, Slovenia; Ž and Physics, University of Ljubljana, Ljubljana, Slovenia

*CURRENT AFFILIATION: ŽAGAR-Meteorologisches Institut, Universität Hamburg, Hamburg, Germany CORRESPONDING AUTHOR: Vlado Malačič, vlado.malacic@nib.si

DOI:10.II75/BAMS-D-18-0II8.I

(C)2019 American Meteorological Society

For information regarding reuse of this content and general

copyright information, consult the AMS Copyright Policy.
}

$8^{\circ} \mathrm{C}$ off the Po River delta (see the inset in Fig. 3 for the locations around the Adriatic Sea) (Artegiani et al. 1997b; Poulain et al. 2001). Elsewhere in the northern Adriatic Sea the SST is a few degrees higher (Solidoro et al. 2009, Figs. 3 and 4). The thermohaline properties of the Gulf of Trieste, the northeastern part of the northern Adriatic, were studied by Malačič et al. (2006) using data during the period 1991-2003. They found that the monthly minimum temperature in winter is $9.2^{\circ} \mathrm{C}$ with $32.8 \mathrm{PSU}$. The seasonal averages of vertical profiles of temperature and salinity of this area put into the perspective of the Mediterranean Sea were studied by Manca et al. (2004). As the lowest SST is well above zero, the conditions needed for seawater to freeze are on average not fulfilled.

Air temperatures in the coastal areas surrounding the northern Adriatic Sea during the winter months vary between $5^{\circ}$ and $10^{\circ} \mathrm{C}$. The winter air temperature may drop below zero during the cold-air outbreaks from the polar region. Such outbreaks bring the polar air toward the Dinaric Alps along the eastern Adriatic Sea coast. This leads to the development of a strong bora wind, which causes hazardous weather conditions over the Adriatic region (Grisogono and Belušić 2009). Most of the bora characteristics are induced by orographic wave breaking and mesoscale pressure gradients across the Dinaric Alps (Gohm et al. 2008; Grubišíc 2004; Petkovšek 1987; Smith et al. 2007). The location of the strongest bora is in the lee of the Velebit mountain range (inset in Fig. 3) that stretches along the eastern coast of the northern Adriatic (Belušić et al. 2013). Strong bora episodes associated with cold outbreaks led to ice formation on coastal structures, boats, and even roads due to high seas along the shoreline (Fig. 1). However, salinity measurements of ice on coastal structures around the Adriatic have not been reported so far.

The Gulf of Trieste (inset in Fig. 3) is a location of the secondary maximum of bora speeds along the northern Adriatic coast (Signell et al. 2010). In contrast, the nearby Bay of Piran, where the reported measurements were taken, is normally protected from 


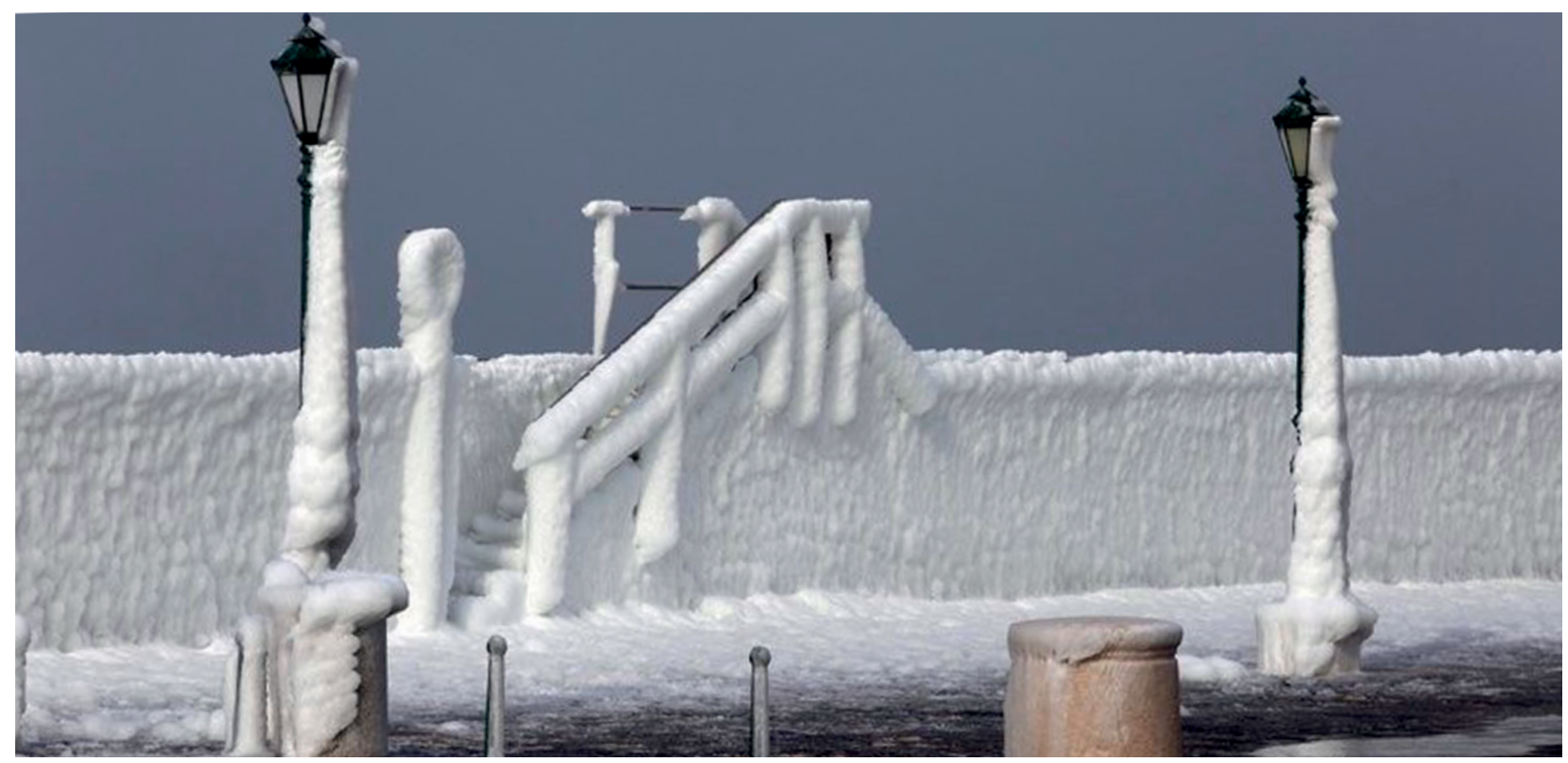

FIG. I. The northern Adriatic coast in the town of Senj on 27 Feb 20I8. (Copyright: G. Kovačić, PIXSELL.)

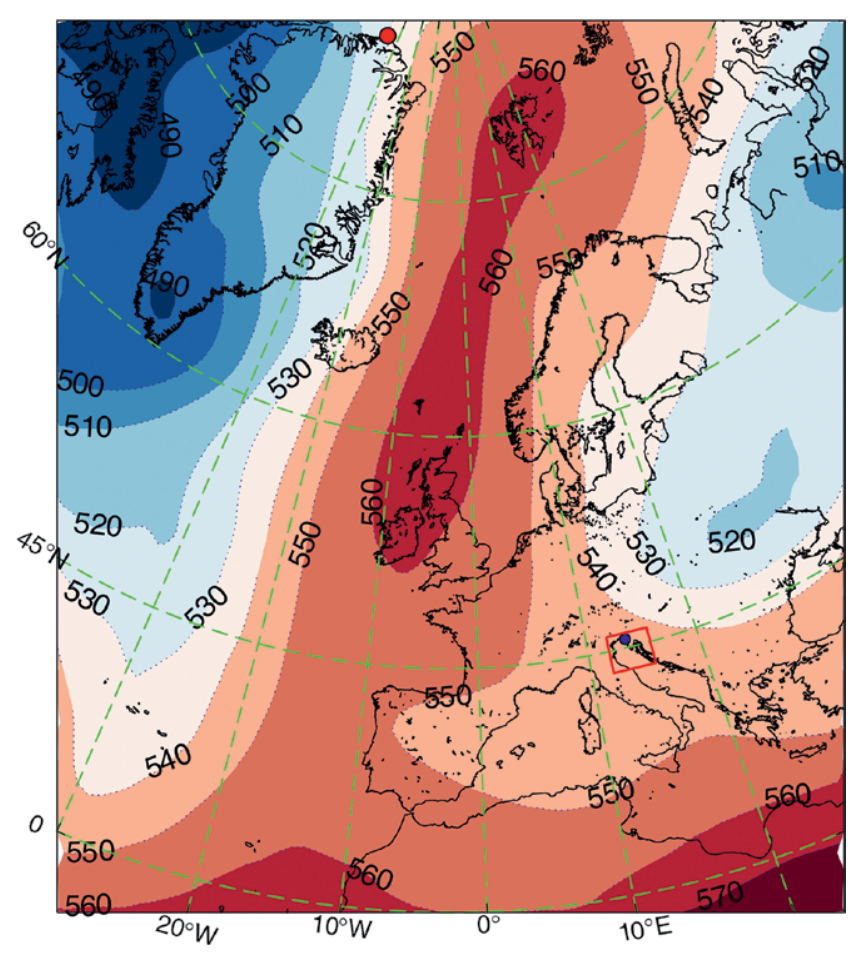

Fig. 2. Geopotential height (dam) at $500 \mathrm{hPa}$ in the Northern Hemisphere at 0000 UTC 25 Feb 2018. The location of the Cape Morris Jesup station in Greenland is marked with a red circle. The location of the coastal buoy Vida, in the northern Adriatic Sea (red rectangle), is marked with the blue circle. [Source: www .ecmwf.int; applied software M_MAP (www.eoas .ubc.ca/ rich/map.html).] severe bora events. Nevertheless, the extreme cold temperatures at the end of February 2018 cooled the air and seawater and provided the necessary conditions for the seawater icicles to form, even in such protected Adriatic pockets.

Records of ice formation in littoral areas of the Adriatic date back to 1929, when ice formed in the shallow brackish lagoons (Grado, Marano, $45.70^{\circ} \mathrm{N}$; inset in Fig. 3) causing the deaths of many organisms, especially mollusks, but also fish (Vatova 1929). The lowest documented air temperature in Rovinj $\left(45.08^{\circ} \mathrm{N}\right)$ during an extreme cold spell was $-12.0^{\circ} \mathrm{C}$ on 11 February 1929 . On the same day the air temperature in Trieste $\left(45.62^{\circ} \mathrm{N}\right)$ dropped to $-14^{\circ} \mathrm{C}$ (Raicich et al. 2013; Vatova 1934). A more recent extreme and long-lasting (3 weeks) bora event in January-February 2012 caused a strong enhancement of the winter circulation of the whole Adriatic, as well as the Mediterranean Sea, with the formation of the densest (density excess above $1,000 \mathrm{~kg} \mathrm{~m}^{-3}$ of $30.58 \mathrm{~kg} \mathrm{~m}^{-3}$ ) water mass ever measured in the northern Adriatic (Carniel et al. 2016; Mihanović et al. 2013; Raicich et al. 2013). In this episode icing in the Venice lagoon also occurred (Ricchi et al. 2016, abstract text). The cold outbreak in this case was associated with a persistent anticyclone over eastern Europe and Russia, and a cyclonic circulation pattern over the Mediterranean (Raicich et al. 2013), a weather pattern known as the "clear bora." In such cases 


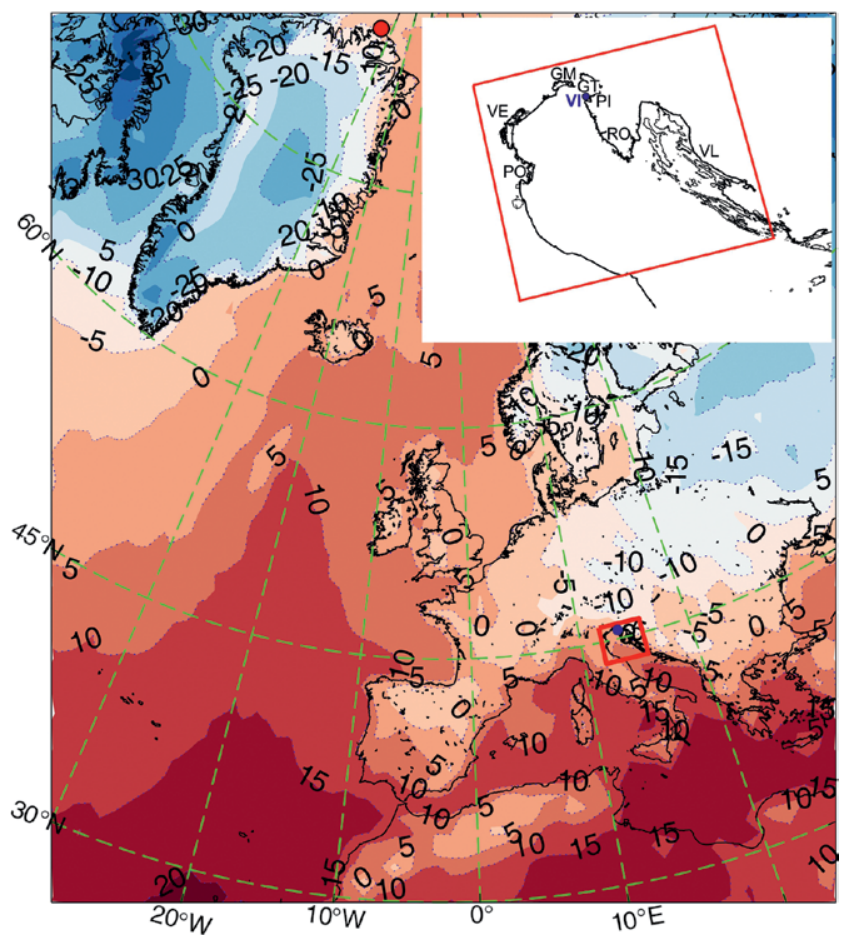

Fig. 3. Surface air temperature $\left({ }^{\circ} \mathrm{C}\right), 2 \mathrm{~m}$ off the ground, at 0000 UTC 25 Feb 2018 ( $w w w . e c m w f$ .int). The inset at the top right shows the northern Adriatic region, focusing on the Po River delta (PO), Venice (VE), Grado-Marano lagoon (GM), the Gulf of Trieste (GT), buoy Vida (VI, blue), Bay of Piran (PI), the town of Rovinj (RO), and the Velebit mountain ridge (VL), a part of the Dinaric Alps. [Applied software M_MAP (www.eoas.ubc .ca/ rich/map.html).]

there is no precipitation in the Adriatic region, but the bora causes high seas and surface heat fluxes leading to the ice formation on coastal structures.

\section{EXTREME SURFACE AIR TEMPERATURES} AROUND GREENLAND AND IN THE ADRIATIC DURING FEBRUARY 2018. The extreme cold spell over central Europe and the Mediterranean at the end of February 2018 was associated with a strong stratospheric warming event that began about 2 weeks earlier. The evolution of the polar vortex at several levels in the stratosphere is available online (http://modes.fmf.uni-lj.si/news /february-2018-stratospheric-vortex). The stratospheric warming began on 11 February, leading to the break of the Arctic polar vortex. The consequences spread into the troposphere and away from the pole in the subsequent 2-3 weeks. The large-scale circulation pattern during the last week of February is illustrated by the operational analyses of the European Centre for Medium-Range Weather Forecasts (ECMWF) in Fig. 2 by using the geopotential height and in Fig. 3 by showing the surface air temperature.

The upper-level circulation was dominated by a large-amplitude wave, aligning southwest-northeast with a ridge extending from northern Africa toward the Arctic, and along a trough stretching from the Arctic toward the Adriatic and Italy. The associated advection of cold air throughout the troposphere brought the polar cold over Europe, whereas the warm advection over the northern Atlantic caused rising temperatures over Greenland. The Arctic was warmer than central Europe and places south of $45^{\circ} \mathrm{N}$. The peak of the positive difference was recorded on 25 February 2018, as shown in Fig. 3. The two stations are Cape Morris Jesup, located in Northeast Greenland National Park $\left(83^{\circ} 39^{\prime} \mathrm{N}, 33^{\circ} 22^{\prime} \mathrm{W}, 4-\mathrm{m}\right.$ height; https://rp5 .ru/Weather_archive_in_Cape_Morris_Jesup), and the coastal buoy Vida, located in the Gulf of Trieste $\left(45^{\circ} 32.925^{\prime} \mathrm{N}, 13^{\circ} 33.042^{\prime} \mathrm{E}, 5-\mathrm{m}\right.$ height; www.nib .si/mbp/en/oceanographic-data-and-measurements /buoy-2/general-2). The stations are $4496 \mathrm{~km}$ apart and their locations are specified in Figs. 2 and 3.

The time series of measurements at the two stations are shown in Fig. 4, which illustrates a remarkable surface warming in the Arctic starting in mid-February 2018. At the time of the peak of the Arctic warming on 25 February, the air temperature at the Cape Morris Jesup station was $4^{\circ}-5^{\circ} \mathrm{C}$ higher than at the coastal buoy Vida (Gulf of Trieste).

Between 10 and 24 February the surface air temperatures at buoy Vida were between $4^{\circ}$ and $9^{\circ} \mathrm{C}$. In Greenland, temperatures were between $-20^{\circ}$ and $-34^{\circ} \mathrm{C}$ from 10 until 14 February, when they started to rise abruptly from $-28^{\circ}$ to almost $3^{\circ} \mathrm{C}$ during the following 8 days. At 1800 UTC 24 February, temperatures in northern Greenland surpassed those measured at the Vida station (i.e., $6.1^{\circ} \mathrm{C}$ at Cape Morris Jesup and $5.6^{\circ} \mathrm{C}$ at Vida) and reached the highest value, $6.2^{\circ} \mathrm{C}$, on that day at 2300 UTC. Higher temperatures in Greenland than those in the northern Adriatic lasted until 1100 UTC 25 February $\left(1.8^{\circ} \mathrm{C}\right.$ at Cape Morris Jesup, $-0.3^{\circ} \mathrm{C}$ at Vida), when they began to drop rapidly. Temperatures in the northern Adriatic decreased at a slower pace, but significantly. Temperatures at the Vida station reached their lowest, $-3.9^{\circ} \mathrm{C}$, at 0730 UTC 26 February and at 0800 UTC 28 February.

Bora winds were relatively strong between 18 and 28 February 2018 (Fig. 4, middle), with the average 

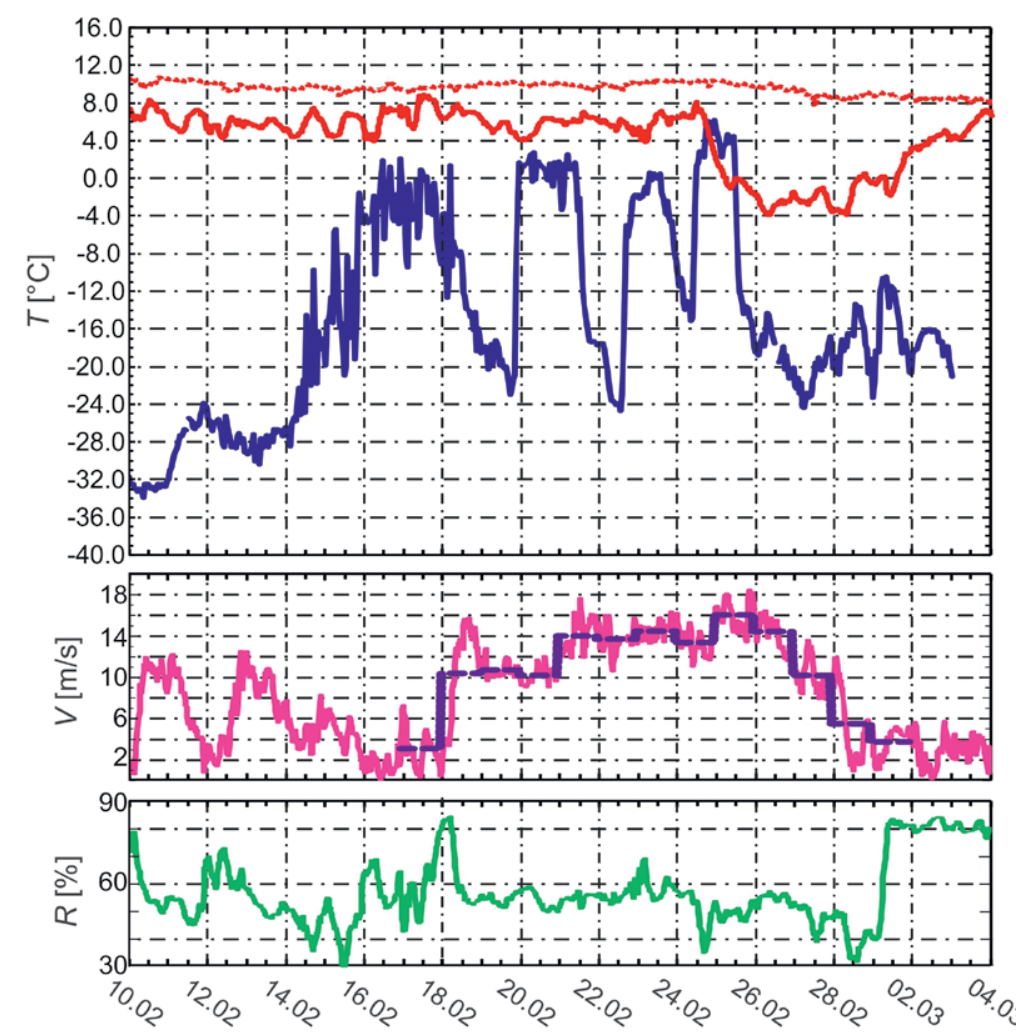

Fig. 4. (top) Temperature measurements from 10 Feb 2018 until 4 Mar 2018 at the coastal buoy Vida: air temperature (red solid line), sea temperature (at 2.5-m depth; red dotted line), and temperature at the Cape Morris Jesup meteorological station (blue line). (middle) The $30-\mathrm{min}$ wind speeds measured at buoy Vida; 24-h moving averages are also plotted (violet) during the episodes of extreme weather. (bottom) Relative humidity. Time is in UTC.

speed varying between 10 and $16 \mathrm{~m} \mathrm{~s}^{-1}$. The relative humidity measured at the Vida buoy ( $3.5 \mathrm{~m}$ above the sea level) was between $55 \%$ and $60 \%$. As bora winds ceased on 1 March 2018 (Fig. 4, bottom) in relation to the lack of dry, cold-air advection on the leeward side of the Dinaric Alps, the humidity increased to its average winter values: around $80 \%$.

At the buoy Vida salinities and surface waves were also measured with a 30-min period. During 23-27 February the salinity was $38.24 \pm 0.17$ PSU, rising in the first part of this period and peaking at 1930 UTC 28 February at 38.53 PSU. This maximum was not surpassed in the later period, 29 February-2 March, when the bora wind ceased (speed below $6 \mathrm{~m} \mathrm{~s}^{-1}$; Fig. 4) and when the salinity was steadier with higher values of $38.43 \pm 0.08$ PSU. The average values of the significant wave heights in these two intervals were $1.14 \pm 0.37 \mathrm{~m}$ and $0.25 \pm 0.16 \mathrm{~m}$, respectively, with the maximum wave height surpassing $3 \mathrm{~m}$ during the strong bora on 21-25 February 2018. The average period of waves was around $3.4 \pm 0.5 \mathrm{~s}$ and $2.2 \pm 0.3 \mathrm{~s}$ during the $23-27$ February and 29 February-2 March periods, respectively.

The advection of cold air toward the Dinaric Alps and the Adriatic, leading to strong bora conditions, is not necessarily coupled with the upper-level circulation. Bora-feeding northeastern flows in winter months typically in the lower troposphere can be accompanied by a warm southeastern flow in the upper troposphere (Belušić et al. 2013; Grisogono and Belušić 2009). However, in the case of February 2018, the advection of cold air from the north occurred throughout the troposphere over Europe and provided conditions for lasting surface cooling, along with the strong bora. The bora and unusually low temperatures were thus the direct consequences of the large-scale circulation associated with the warming over Greenland.

\section{MEASUREMENTS OF SALINITY OF THE MELTED SEAWATER ICI- CLES. Applied instrument and method. Salinity of melted icicles was measured using an MSS 90 microstructure CTD probe [Sea\&Sun Technology (SST); www .sea-sun-tech.com/fileadmin/img/pdf_sea Isst_mss90-2.pdf], which is otherwise} designed for measuring turbulence in coastal seas (Falcieri et al.2016). Its sensors are annually validated and calibrated. We may infer that the accuracy of the temperature measurements was $0.006^{\circ} \mathrm{C}$, with the second decimal being reliable, while the conductivity sensor values differed from the reference values for less than $0.008 \mathrm{~S} \mathrm{~m}^{-1}$, where the second decimal of the conductivity value was also reliable $\left(0.005 \mathrm{~S} \mathrm{~m}^{-1}\right.$ for the conductivity value in question). During measurements of salinity the temperature of the icicles was of $12.29^{\circ}$ $\pm 0.08^{\circ} \mathrm{C}$ and the conductivity fluctuated around the mean $11.88 \mathrm{~S} \pm 0.02 \mathrm{~S} \mathrm{~m}^{-1}$. This means that the accuracy of salinity measurements, calculated from temperature and conductivity according to the 1978 definition of practical salinity (UNESCO 1978), stands firm at least for the first decimal.

Salinity measurements. Icicles on the railing of a staircase (Fig. 5) were knocked off, broken, and placed in an 
airtight, 35-L PVC bucket (0.36-m height, 0.34-0.39-m diameter) on 27 February 2018, a few days into the cold episode. The bucket was left outdoors until 7 March 2018, when all the ice in the bucket had melted into over $30 \mathrm{~L}$ of water, into which we lowered the microstructure probe; all of the probe's sensors were submerged in water.

Five sets of measurements of the temperature and conductivity of the melted sea ice were recorded on 7 March within 6 min, each measurement taking between 11 and $31 \mathrm{~s}$. The measurements were streamed to a portable computer at a rate of $1024 \mathrm{~s}^{-1}$; therefore, the number of data points for each set of measurements was between 11,729 and 31,704 (Table 1). One notices that although within each set of measurements the variability of the temperature values is relatively small $\left(0.002^{\circ} \mathrm{C}\right.$ at most), the temperature of the melted icicles varied on the first decimal from one dataset to another. Indeed, it ranged from $12.20^{\circ}$ to $12.39^{\circ} \mathrm{C}$. The conductivity was steady on the second decimal $\left(1.19 \mathrm{~S} \mathrm{~m}^{-1}\right)$.
Measurements of temperature and conductivity allowed us to confidently determine the salinity as $9.2 \pm 0.02 \mathrm{PSU}$ (using conservative figures), leading to a density excess (UNESCO 1987) as $6.6 \pm 0.02 \mathrm{~kg} \mathrm{~m}^{-3}$. The salinity value is within the range of values needed to reasonably infer that the icicles were made of seawater (Cox and Weeks 1974). As such, it has been found that at the end of the growth season the average salinity of "thin" (polar) ice sheets is a linear function of its thickness. To determine the "thickness of the icicles" $h$, the equation for salinity of ice sheets can be used for our purposes (Cox and Weeks 1974): $S=14.24-19.39 h(h \leq 0.4 \mathrm{~m})$. If for $S$ the mean value is applied, one gets $h \leq 0.25 \mathrm{~m}$.

Although the icicles have a very anisotropic shape (up to $0.5 \mathrm{~m}$ in length and $0.05 \mathrm{~m}$ in width), this dimension measure fits the studied icicles. We also must consider that it is the length of the icicles that corresponds to the thickness of the ice, because it is mostly in this direction that the brine water leaves the icicles through tubes inside the ice. The shape of

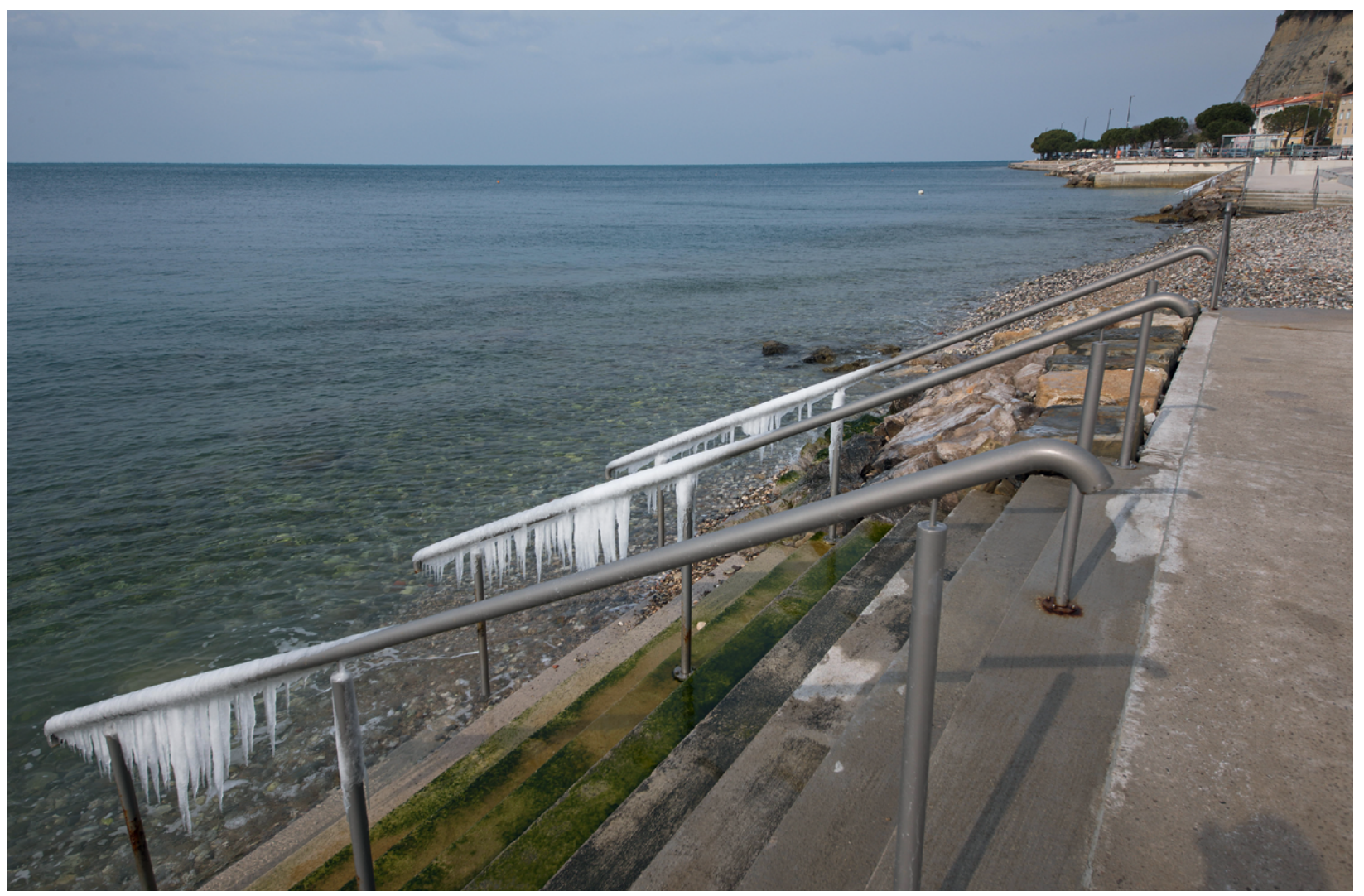

FIG. 5. Icicles on the railing of a staircase that leads into the Bay of Piran (the Gulf of Trieste, $45.52^{\circ} \mathrm{N}$ ) at 1300 UTC 27 Feb 2018, a few days after temperatures began to drop in the area. Typical dimensions of the railing are $3.9 \mathrm{~m}$ in length and $\mathrm{I} \mathrm{m}$ in height, while the rods are $\mathbf{0 . 0 5} \mathrm{m}$ in diameter. (Photo courtesy of T. Makovec.) 
TABLE I. Measurement data for the temperature and conductivity of melted icicles. The number of data points in each set is shown in column $2, \max$ is the maximum value of that set, $\min$ is the minimum value, std dev is the standard deviation, and all refers to all five sets of data combined.

\begin{tabular}{|c|c|c|c|c|c|c|}
\hline Series & No. & Statistics & $T\left({ }^{\circ} \mathrm{C}\right)$ & $C\left(\mathrm{~S} \mathrm{~m}^{-1}\right)$ & $S$ (PSU) & $\sigma\left(\mathrm{kg} \mathrm{m}^{-3}\right)$ \\
\hline \multirow{5}{*}{ I } & \multirow{5}{*}{11,729} & Mean & 12.203 & 1.187 & 9.203 & 6.605 \\
\hline & & Median & 12.203 & 1.187 & 9.203 & 6.605 \\
\hline & & Min & 12.200 & 1.186 & 9.200 & 6.603 \\
\hline & & Max & 12.206 & 1.187 & 9.206 & 6.608 \\
\hline & & Std dev & 0.001 & $1 \times 10^{-4}$ & $8 \times 10^{-4}$ & $7 \times 10^{-4}$ \\
\hline \multirow{5}{*}{2} & \multirow{5}{*}{15,384} & Mean & 12.212 & 1.187 & 9.203 & 6.604 \\
\hline & & Median & 12.212 & 1.187 & 9.203 & 6.604 \\
\hline & & Min & 12.208 & 1.187 & 9.200 & 6.602 \\
\hline & & Max & 12.216 & 1.187 & 9.206 & 6.606 \\
\hline & & Std dev & 0.002 & $1 \times 10^{-4}$ & $8 \times 10^{-4}$ & $7 \times 10^{-4}$ \\
\hline \multirow{5}{*}{3} & \multirow{5}{*}{$|0,74|$} & Mean & 12.221 & 1.187 & 9.203 & 6.603 \\
\hline & & Median & 12.222 & 1.187 & 9.203 & 6.603 \\
\hline & & Min & 12.219 & 1.187 & 9.200 & 6.601 \\
\hline & & Max & 12.225 & 1.188 & 9.206 & 6.605 \\
\hline & & Std dev & 0.001 & $1 \times 10^{-4}$ & $8 \times 10^{-4}$ & $7 \times 10^{-4}$ \\
\hline \multirow{5}{*}{4} & \multirow{5}{*}{18,954} & Mean & 12.384 & 1.189 & 9.175 & 6.559 \\
\hline & & Median & 12.383 & 1.189 & 9.175 & 6.559 \\
\hline & & Min & 12.381 & 1.188 & 9.171 & 6.555 \\
\hline & & Max & 12.388 & 1.189 & 9.180 & 6.563 \\
\hline & & Std dev & 0.001 & $2 \times 10^{-4}$ & 0.002 & 0.001 \\
\hline \multirow{5}{*}{5} & \multirow{5}{*}{31,704} & Mean & 12.355 & 1.191 & 9.202 & 6.584 \\
\hline & & Median & 12.355 & 1.191 & 9.202 & 6.584 \\
\hline & & Min & 12.352 & 1.191 & 9.199 & 6.581 \\
\hline & & Max & 12.357 & 1.191 & 9.206 & 6.586 \\
\hline & & Std dev & $7 \times 10^{-4}$ & $1 \times 10^{-4}$ & 0.001 & $7 \times 10^{-4}$ \\
\hline \multirow{5}{*}{ All } & \multirow{5}{*}{88,512} & $\begin{array}{l}\text { Mean } \\
\text { (mean) }\end{array}$ & 12.275 & 1.188 & 9.197 & 6.591 \\
\hline & & $\begin{array}{c}\text { Median } \\
\text { (mean) }\end{array}$ & 12.222 & 1.187 & 9.203 & 6.603 \\
\hline & & Min & 12.200 & 1.186 & 9.171 & 6.555 \\
\hline & & Max & 12.388 & 1.191 & 9.206 & 6.608 \\
\hline & & $\begin{array}{l}\text { Std dev } \\
\text { (mean) }\end{array}$ & 0.087 & 0.002 & 0.012 & 0.020 \\
\hline
\end{tabular}

the icicles on the railings, shown in Fig. 5, confirms that $0.25 \mathrm{~m}$ is a reasonable estimate of the icicle dimensions.

SUMMARY. Marine icicles by the Adriatic (and Mediterranean) Sea are rare events and may form when there are strong outbreaks of polar air across Europe toward the Adriatic. In an exceptionally strong outbreak of cold air during the last week of February 2018, the surface air temperatures at the northern tip of Greenland were positive and higher than those recorded in the Adriatic Sea region, over $4,000 \mathrm{~km}$ to the south. The freezing temperatures were recorded along the eastern Adriatic coast. Strong bora winds caused high seas and breaking waves along the coast. The ice formed on coastal structures even in places normally protected from the wind, like the Bay of Piran. We provide evidence that marine icicles formed on these occasions were made of seawater.

For salinities in the interval 38.0-38.5 PSU, the seawater freezing point is around $-2.1^{\circ} \mathrm{C}$ (UNESCO 1983), which is a lowerthan-average temperature for the northern Adriatic. The air temperature measured at the buoy Vida in the Bay of Piran in the northern Adriatic between 26 and $28 \mathrm{Feb}$ ruary dropped to values as low as $-3.9^{\circ} \mathrm{C}$. This enabled the seawater to freeze as it was lifted into the air by breaking waves, forming icicles on the railings of littoral staircases and on other structures along the shoreline. The measured salinity of the melted icicles was around 9 PSU. This is also a typical value for marine ice found in polar regions (Cox and Weeks 1974). This is the first such study focusing on the Adriatic region and it establishes that the icicles were formed of seawater.

ACKNOWLEDGMENTS. The authors are indebted to Sergey Chvilev of Raspisaniye Pogodi Ltd., who kindly offered valuable support interpreting the data from the Cape Morris Jesup station. We are also indebted to Tihomir Makovec for the technical support for the salinity measurements of icicles, and to Blaž Jesenko of the Faculty of Mathematics and 
Physics, University of Ljubljana, for support in handling the meteorological data. Financial support was provided by the Slovenian Research Agency (P1-0237 and 630-11/2017-1 for VM and P1-0188 and J1-9431 for NŽ).

\section{FOR FURTHER READING}

Artegiani, A., D. Bregant, E. Paschini, N. Pinardi, F. Raicich, and A. Russo, 1997a: The Adriatic Sea general circulation. Part I: Air-sea interactions and water mass structure. J. Phys. Oceanogr., 27, 1492-1514, https://doi.org/10.1175/1520-0485(1997)027<1492:TA SGCP $>2.0 . C O ; 2$.

,,,,----- , and,$- 1997 \mathrm{~b}$ : The Adriatic Sea general circulation. Part II: Baroclinic circulation structure. J. Phys. Oceanogr., 27, 1515-1532, https://doi.org/10.1175/1520-0485(1997)027<1515:TA SGCP $>2.0 . \mathrm{CO} ; 2$.

Belušić, D., M. Hrastinski, Ž. Večenaj, and B. Grisogono, 2013: Wind regimes associated with a mountain gap at the northeastern Adriatic coast. J. Appl. Meteor. Climatol., 52, 2089-2105, https://doi.org/10.1175 /JAMC-D-12-0306.1.

Carniel, S., A. Benetazzo, D. Bonaldo, F. M. Falcieri, M. M. Miglietta, A. Ricchi, and M. Sclavo, 2016: Scratching beneath the surface while coupling atmosphere, ocean and waves: Analysis of a dense water formation event. Ocean Modell., 101, 101-112, https:/doi .org/10.1016/j.ocemod.2016.03.007.

Cox, G. F. N., and W. F. Weeks, 1974: Salinity variations in sea ice. J. Glaciol., 13, 109-120, https://doi .org/10.1017/S0022143000023418.

Ehn, J. K., B. J. Hwang, R. Galley, and D. G. Barber, 2007: Investigations of newly formed sea ice in the Cape Bathurst polynya: 1 . Structural, physical, and optical properties. J. Geophys. Res., 112, C05002, https://doi .org/10.1029/2006JC003702.

Falcieri, F. M., and Coauthors, 2016: Turbulence observations in the Gulf of Trieste under moderate wind forcing and different water column stratification. Ocean Sci., 12, 433-449, https://doi.org/10.5194 los-12-433-2016.

Gohm, A., G. J. Mayr, A. Fix, and A. Giez, 2008: On the onset of bora and the formation of rotors and jumps near a mountain gap. Quart. J. Roy. Meteor. Soc., 134, 21-46, https://doi.org/10.1002/qj.206.

Grisogono, B., and D. Belušić, 2009: A review of recent advances in understanding the meso- and microscale properties of the severe bora wind. Tellus, 61A, 1-16, https://doi.org/10.1111/j.1600-0870.2008.00369.x.
Grubišíc, V., 2004: Bora-driven potential vorticity banners over the Adriatic. Quart. J. Roy. Meteor. Soc., 130, 2571-2603, https://doi.org/10.1256/qj.03.71.

Malačič, V., M. Celio, B. Čermelj, A. Bussani, and C. Comici, 2006: Interannual evolution of seasonal thermohaline properties in the Gulf of Trieste (northern Adriatic) 1991-2003. J. Geophys. Res., 111, C08009, https://doi.org/10.1029/2005JC003267.

Manca, B., M. Burca, A. Giorgetti, C. Coatanoan, M. J. Garcia, and A. Iona, 2004: Physical and biochemical averaged vertical profiles in the Mediterranean regions: An important tool to trace the climatology of water masses and to validate incoming data from operational oceanography. J. Mar. Syst., 48, 83-116, https://doi.org/10.1016 /j.jmarsys.2003.11.025.

Mihanović, H., and Coauthors, 2013: Exceptional dense water formation on the Adriatic shelf in the winter of 2012. Ocean Sci., 9, 561-572, https://doi.org/10.5194 los-9-561-2013.

Petkovšek, Z., 1987: Main bora gusts-A model explanation. Geofizika, 4, 41-50.

Poulain, P.-M., V. Kourafalou, and B. Cushman-Roisin, 2001: Northern Adriatic Sea. Physical Oceanography of the Adriatic Sea, Past, Present and Future, B. Cushman-Roisin et al., Eds., Kluwer Academic Press, 143-165.

Raicich, F., V. Malačič, M. Celio, D. Giaiotti, C. Cantoni, R. R. Colucci, B. Čermelj, and A. Pucillo, 2013: Extreme air-sea interactions in the Gulf of Trieste (north Adriatic) during the strong bora event in winter 2012. J. Geophys. Res. Oceans, 118, 5238-5250, https://doi.org/10.1002/jgrc.20398.

Ricchi, A., M. M. Miglietta, P. P. Falco, A. Benetazzo, D. Bonaldo, A. Bergamasco, M. Sclavo, and S. Carniel, 2016: On the use of a coupled ocean-atmospherewave model during an extreme cold air outbreak over the Adriatic Sea. Atmos. Res., 172-173, 48-65, https:// doi.org/10.1016/j.atmosres.2015.12.023.

Signell, R., J. Chiggiato, J. Horstmann, D. Doyle James, J. Pullen, and F. Askari, 2010: High-resolution mapping of bora winds in the northern Adriatic Sea using synthetic aperture radar. J. Geophys. Res., 115, C04020, https://doi.org/10.1029/2009JC005524.

Smith, R. B., J. D. Doyle, Q. Jiang, and S. A. Smith, 2007: Alpine gravity waves: Lessons from MAP regarding mountain wave generation and breaking. Quart. J. Roy. Meteor. Soc., 133, 917-936, https://doi .org/10.1002/qj.103.

Solidoro, C., and Coauthors, 2009: Current state, scales of variability, and trends of biogeochemical properties 
in the northern Adriatic Sea. J. Geophys. Res., 114, C07S91, https://doi.org/10.1029/2008JC004838.

UNESCO, 1978: Ninth report of the Joint Panel on Oceanographic Tables and Standards. UNESCO Tech. Papers in Marine Science, No. 30, 33 pp.

_ 1983: Algorithms for computation of fundamental properties of seawater. UNESCO Tech. Papers in Marine Science, No. 44, 53 pp.

_-, 1987: International Oceanographic Tables.
UNESCO Tech. Papers in Marine Science, No. 40, Vol. 4, 195 pp.

Vatova, A., 1929: Sui minimi termici verificatisi nell' Alto Adriatico nel febbraio e marzo 1929 e loro effetti sull'ittiofauna. Mem. Roy. Com. Talassogr. Ital., 157, 1-9.

—-, A., 1934: L'anormale regime fisico-chimico dell'Alto Adriatico nel 1929 e le sue ripercussioni sulla fauna. Thalassia, 1, 1-49.
Weather in the Courtroom

Memoirs from a Career in

Forensic Meteorology

William H. Haggard

From a pioneering forensic meteorologist...

The inside scoop on legendary litigations where the weather may-or may not-have played a crucial role, including:

- The disappearance of an Alaskan congressman's airplane in 1972

- The collapse of Tampa Bay's Skyway Bridge in 1980

- The crash of Delta Flight 191 in Dallas/FortWorth in 1985

William H. Haggard is former director of the NCDC and AMS certified consulting meteorologist (CCM), fellow, and honorary member.

(C) 2016, paperback, 240 pages

ISBN 13: 978-I-940033-95-2

List price: $\$ 30$ AMS Member price: $\$ 20$
WEATHER

IN THE

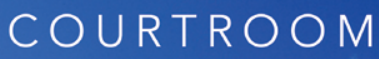

MEMOIRS FROM A CAREER IN FORENSIC METEOROLOOY

William H. Haggard

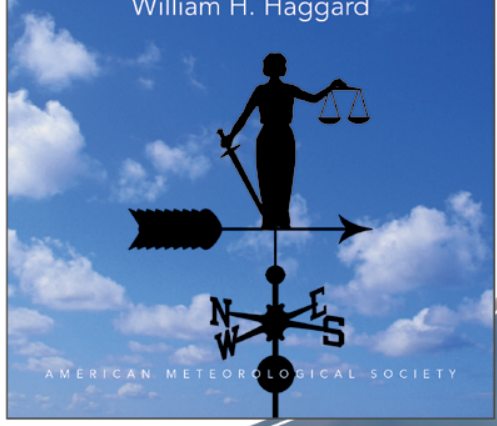

AMS BOOKS

RESEARCH APPLCATIONS HISTORY

bookstore.ametsoc.org 